\title{
Comparative analysis of the repellency activity of single compounds and the synthetic blends of semiochemicals from Aframomum melegueta (R.schum) and Dennittia tripetala (Bak.F) against Rhizopertha dominica in Calabar, Nigeria
}

\author{
${ }^{1}$ Lawrence Ahmed Ugbe and ${ }^{2}$ Emmanuel B. Adie \\ ${ }^{1}$ Department Of Agriculture, Federal College Of Education Obudu, In Affiliation With The \\ University Of Calabar, Calabar Cross River State. \\ 2. Department Of Crop Science, University Of Calabar, Calabar Cross River State \\ Corresponding author: ugbeahmed@g.mail.com
}

\begin{abstract}
Bioassay experiments were carried out in Calabar to compare the repellency activity of single compounds and the synthetic blends of Semiochemicals extracted from Afromomum melegueta and Dennittia tripetala. The aim of the experiment was to determine the efficacy of single compounds and the synthetic blends in suppressing the reproductive potential and adult emergence of Rhizopertha dominica, (Fabricius), a primary pest of stored cassava pellets and cereal grains in Sub-Saharan Africa. Insect culture of the adult $R$. dominica was set up in the laboratory at Federal College of Education Obudu to obtain fresh insects for the bioassay experiments. Dried seeds of A. melegueta (R. Schum) and $D$. tripetala (Baker f.) Schatz were procured from the main market in Obudu for the purpose of the research work. 100g each of the dried fruits of the spice plants were pounded separately with the laboratory pestle and mortar for the extraction of the essential oils (EOs). The oils extracted were tested for toxicity and reproductive potential deterrence against $R$. dominica. The chemical constituents of the essential oils were isolated, identified and tested against $R$. dominica. Synthetic blends of individual compounds were prepared based on their natural ratios and were also tested for toxicity and reproductive potential deterrence against the insect pests in the laboratory. The result showed that both the single compounds and the synthetic blends were toxic and repellent to the insect pest, and could significantly suppress the reproductive potential thereby inhibiting the emergence of adult insect. However, synthetic blends exhibited a stronger efficacy in their toxicity against the pest thereby providing a broad spectrum of insecticidal bioactivity against $R$. dominica than the single compounds. This action of the synthetic blends of extracts from the spice plants demonstrated their potential for development in stored products protection especially at the small scale resource poor farmer's level in Nigeria.
\end{abstract}

Keywords:Toxicity, Reproductive potential, Synthetic blend, Bioactivity, Oviposition, Deterrence, Essential oils (EOs).

\section{Introduction}

In Nigeria and in most African countries, farmers harvest their crops, dry them and then store in traditional manner, which are open storage facilities that are only capable of holding just about 1000 to $1,500 \mathrm{kgs}$ of the total grains harvested for the year (Duke et al, 2003). Greater part of this stored grains are often times damaged by insect pests that infest them. Several figures have been estimated in literatures on the extent of damage of stored grains resulting from insect pest attacks. For instance, Duke et al. (2003) reported that about 15 to $20 \%$ losses were recorded the world over, and 30 to $40 \%$ in the tropics. In West Africa. 25 to $30 \%$ of stored of maize have been destroyed only within few months of storage. (Holst et al., 2002; Meikle et al., 2002). These attacks on maize by the insect pests, usually occur when the moisture content of the grains is between $30 \%$ and $40 \%$ (Adda et al., 2002)

The lesser grain borer, Rhyzoperth dominica (Fabricius) Bostrichidae is one of the most important economic insect pests of dried cassava chips and pellets and also attack stored grains in the tropical and sub-tropical regions of the world. The insect is also known to be a pest of whole cereals, even of rough rice which is resistant to the attack of most 
Lawrence Ahmed Ugbe and Emmanuel B. Adie: Comparative analysis of the repellency activity of single compounds and the synthetic blends of semiochemicals from Aframomum melegueta (R.schum) and Dennittia tripetala (Bak.F) against Rhizopertha dominica in Calabar, Nigeria

storage pests. (Adda et al, 2002). The females prefer to lay their eggs in crevices or on the rough surfaces of a seed. On emergence, the larvae will make use of even minute husk defects to bore into the grain (Add et al., 2002). In undamaged grains, adult most frequently attack the grain. Beside whole cereals, $R$. dominica will develop on milled rice and cereal flours but not on highly polished rice. Dried cassava can be severely damaged by $R$. dominica, which is a major pest of the commodity.

There have been several reports of small populations of $R$. dominica on cereals in the field before harvest but infestation is mostly post-harvest. Considerable weight losses occur as a result of heavy attack and further damage may be done by the insects boring into the wooden structures of the store. Commodities infested by $R$. dominica rarely become mouldy. It would seem that this species does not raise the moisture content of the food to the same extent as Sitophilus spp which can cause a considerable increase (Duke et al., 2003). The consequences of insect pests infestations is enormous and the economic damage they cause, relates to the physical loss of the commodity, spoilage and loss of quality of the product including the encouragement of mould growth such as Mycotoxin, Ochratoxin A and Citrinin produced by Penincillium vevrucosun (Hubert, Munzbergova, and Santino, 2008).

The control of insect pests of crops usually involves the use of synthetic pesticides namely; the Organo-phosphate and Organochlorines which are associated with adverse effects such as the destruction of the ecosystem, mammalian toxicity and the development of resistance by the insect pests (Duke et al., 2003). In modern times, research has emphasized the use of plants essential oils, their chemical constituents and other compounds (plant powders, plant extracts, and nonvolatile oils) as possible substitute to fumigants or synthetic residual pesticides
(Ogendoet al., 2008). However, these plant base pesticides are specific to the target species and have local availability (Isman, 2006). Research has shown that single compounds of extracts from A. melegueta and $D$. tripetala can, to some certain level successfully repel $R$. dominica and suppress oviposition, hence the insect's reproductive potential. Therefore, the objective of the research work was to evaluate the efficacy of the synthetic blends of the extracts from $A$. melegueta and D. tripetala in repelling $R$. dominica, deterring oviposition and suppressing the reproductive potential of the insect in stored dry cassava chips.

\section{Materials and methods}

\subsection{Insect culture and the collection of materials}

Insect culture was established with adult $R$. dominica collected from infested cassava pellets in a food shop in Obudu market in Cross River State. The insect culture was kept at room temperature in a laboratory at the Agricultural Department, Federal College of Education, Obudu where the bioassay experiments were conducted. The culture was sieved after three days to obtain fresh insects for the experiments. Some quantity of dry, clean and uninfested cassava pellets were procured from the same market for use in the bioassay experiments. Also procured were fresh, ripe fruits of $A$. melegueta and $D$. tripetala. They were washed and dried under the sun for the purpose of the experiment.

\subsection{Extraction of essential oils (EOs) from A.} melegueta and D. tripetala

A hundred gramme (100g) each of dried fruits of A. melegueta and D. tripetala were separately ground into powder using laboratory pestle and mortar. The powder of A. melegueta was dissolved in a $50 \mathrm{ml}$ of redistilled diethyl ether. The container was immersed in an ultrasonic wave device for 5 minutes to disperse and homogenize the 
Lawrence Ahmed Ugbe and Emmanuel B. Adie: Comparative analysis of the repellency activity of single compounds and the synthetic blends of semiochemicals from Aframomum melegueta (R.schum) and Dennittia tripetala (Bak.F) against Rhizopertha dominica in Calabar, Nigeria

contents. The vacuum distillation apparatus was then connected to a high vacuum pump (ES 50 vacuum pump. Edwards, England). The glass sections of the apparatus were strongly heated with a hot air blower to remove any less volatile contaminants from its internal surface. The tube which is in Uform and the pear shape vessel meant for the collection of the distillate were submerged completely in nitrogen at a temperature of $196^{\circ} \mathrm{C}$. The residue extracted was then distilled for 24 hours at a pressure of 0.05 mmHg. D. tripetala powder was vaccum distilled in a similar manner as explained above. The ether distillates of these substances were then pipetted from the vacuum distillation apparatus through long drawn Pasteur pipettes into $50 \mathrm{ml}$ separation funnels to remove water. The extracts were dried using Magnesium Sulphate $\left(\mathrm{MgSO}_{4}\right)$, then filtered and concentrated in order to obtain $4 \mathrm{ml}$ each of $A$. melegueta and $D$. tripetala essential oils (EOs) according to the work of Bouda, Tapondjou, Fontam, and Gumedzoe (2001). Each of the vacuum distilled extract was sealed under nitrogen, labeled accordingly and placed in different ampoules, pending when they were needed for the laboratory bioassay experiments.

\subsection{Isolation of the chemical constituents of the essential oils (EOs)}

Gas-Chromatography-Mass Spectrometry (GC-MS) was conducted in order to identify and isolate the chemical constituents of the polar and non-polar fractions of the essential oils from the two spice plants (A.melegueta and $D$. tripetala) and to test them for bioactivity against $R$. dominica. The GC-MS analysis was carried out using agilent technology Model 7890A, interfaced with mass selective Detector (MSD) Model 5975C. An electron ionization was at a $70 \mathrm{ev}$ with an ion source temperature of $250^{\circ} \mathrm{C}$. Helium gas was used as a carrier gas while Hp-5ms (30mm $\times 0.25 \mathrm{~mm}$ ) was used as the stationary phase. The oven temperature was maintained at $75^{\circ} \mathrm{C}$ for five minutes and ramped to $250^{\circ} \mathrm{C}$ at the rate of $3.5^{\circ} \mathrm{C}$ per minute for 6 minutes. $1 \mathrm{ml}$ essential oil (EO) each of $A$. melegueta and $D$. tripetala were separately injected into the chromatographic column for analysis of the chemical constituents, which were later separated out for the two spice plants.

However, hexane was identified as the nonpolar compound while florisil diethyl ether fractions were the polar compounds. The major compounds isolated from the forisil diethyl ether of the two spice plants were $0.1 \mathrm{mg} / \mathrm{ml}(\mathrm{S})$ - 2- heptanol, $0.6 \mathrm{mg} / \mathrm{ml}$ (S) $-2-$ helptyl acetate and $0.3 \mathrm{mg} / \mathrm{ml}(\mathrm{R})$ linolool for A. melegueta and $0.3 \mathrm{mg} / \mathrm{ml} \mathrm{1,3-}$ Cyclopentadiene, $0.5 \mathrm{mg} / \mathrm{ml} \quad 1,6-$ Cyclodecadien, $0.2 \mathrm{mg} / \mathrm{ml} 2$ - Undecene for D. tripetala, in their natural ratios of 1:6:3 v/v A. melegueta and 3:4:3 v/v for D. tripetala respectively.

2.4 Preparation of synthetic blends from the diethyl ether compounds of the two spice plants

Synthetic blend of $0.1 \mathrm{mg} / \mathrm{ml}$ (S) - $2-$ heptanol, $0.6 \mathrm{mg} / \mathrm{ml}(\mathrm{S})-2$ - heptyl acetate, and $0.3 \mathrm{mg} / \mathrm{ml}(\mathrm{R})$ - linolool diethyl ether fractions of $A$. melegueta was prepared by dissolving $0.1 \mathrm{mg} / \mathrm{ml}$ of 2-heptanol, $0.6 \mathrm{mg} / \mathrm{ml}$ of (2) - heptyl acetate and $0.3 \mathrm{mg} / \mathrm{ml}$ of (R)linolool in $10 \mathrm{ml}$ flask, then $1 \mathrm{ml}$ of each compound was combined in a $10 \mathrm{ml}$ volumetric flask filled up with hexane. Similarly, blend of the major components of diethyl ether fractions of $D$. tripetala was prepared by dissolving $0.3 \mathrm{mg} / \mathrm{ml}$ of 1,3 Cyclopentadien, $0.5 \mathrm{mg} / \mathrm{ml}$ of 2Undecentand $0.2 \mathrm{mg} / \mathrm{ml}$ Cyclodecadienin 10 $\mathrm{ml}$ flask, then $1 \mathrm{ml}$ of each of the compound was combined in a $10 \mathrm{ml}$ volumetric flask filled up with hexane according to the methods of (Ukeh, Birkett, Bruce, Allan, Pickett and Mordue, 2020). The synthetic solutions were sealed in ampoules under 
Lawrence Ahmed Ugbe and Emmanuel B. Adie: Comparative analysis of the repellency activity of single compounds and the synthetic blends of semiochemicals from Aframomum melegueta (R.schum) and Dennittia tripetala (Bak.F) against Rhizopertha dominica in Calabar, Nigeria

nitrogen for storage pending when they were needed for the bioassay experiments.

\subsection{Toxicity effect of the plant essential oil} (EO) extracts and their synthetic blend on $R$. dominica

Each plant essential oil (EO) extract $(5,10$, and $15 \mu \mathrm{l})$ was impregnated separately into filter paper and placed at the bottom of a plastic container, while the same quantity of the essential oil was also separately applied round the inside of the same container. Twenty (20) pairs of three day old $R$. dominica were introduced into the containers for oviposition to take place. All treatments were replicated four (4) times and arranged in Complete Randomized Design (CRD). Mortality count was done every 24 hours for 72 hours after the introduction of the insects into the separate containers. On each count, after every two days, dead insects were removed by sieving, counted and discarded while the emerging new insects were also counted and returned to the container and then recorded. Until no more new insect emerged. The same procedure was carried out when the chemical constituents of the Mean No. emerged adult in control-mean no. emerged adult in treated $\quad$ X 100 Mean no of emerged adult in control.

According to the method of Ukeh et al. (2010).

\subsection{Data Analysis}

All data generated were subjected to analysis of variance (ANOVA) procedure and means were compared using Tukey's simultaneous means separation, according to Zar (1999) or least significant difference (LSD) at 0.05 level of probability. Mentab 15 statistical software was used for the analysis of data.

\section{Results}

The essential oils (EOs) extracted from the two spice plants were tested individually for bioactivity (Toxicity and oviposition essential oils were isolated and the single compounds and their synthetic blends were separately impregnated into filter paper and some quantities of the oils applied on the inside of the containers in order to conduct the mortality test on the insect pest, $R$. dominica. The mortality experiment was to study the efficacy of the synthetic blends in suppressing the oviposition potential of the insect thereby prevening the emergence of the $\mathrm{F}_{1}$ progeny insects from the eggs laid. Ten insects were randomly selected from each of the four replicates during the first time that counting was done, and then weighed using Sartorious weighing balance.

Data obtained in this experiment were analyzed using analysis of variance (ANOVA) procedure, after which the data were further transformed using the formula $\log _{10} x+1$ in order to remove the aspect of zero and to ensure that they do not conflict with the analysis of variance.

\subsection{Reproductive potential deterrence effect}

Based on the data obtained from toxicity effect, the percentage reproductive potential deterrence effect was calculated as follows: 
Lawrence Ahmed Ugbe and Emmanuel B. Adie: Comparative analysis of the repellency activity of single compounds and the synthetic blends of semiochemicals from Aframomum melegueta (R.schum) and Dennittia tripetala (Bak.F) against Rhizopertha dominica in Calabar, Nigeria

exhibited the highest toxicity against the insect by recording the highest mortality of the insects compared to the untreated and at 5 $\mu \mathrm{l}$ of the oil. Dennittia tripetala essential oil was equally toxic to the insect pests $(R$. dominica) at $10 \mu \mathrm{l}$ and $15 \mu \mathrm{l}$ but not as toxic as essential oil from $A$. melegueta (Table 1).

Table 1: Effect of essential oil (EO) extracts of $A$. melegueta and $D$. tripetala on the mortality count of $R$. dominica at 24,48 and 72 hours post treatment in the laboratory

\begin{tabular}{llll}
\hline \multicolumn{4}{c}{ Cumulative mean \% mortality } \\
\hline Treatments & $\mathbf{2 4}$ hours & $\mathbf{4 8 ~ h o u r s}$ & $\mathbf{7 8 ~ h o u r s}$ \\
\hline Control & $9.35 \pm 1.25^{\mathrm{a}}$ & $9.62 \pm 1.40^{\mathrm{a}}$ & $9.82 \pm 1.20^{\mathrm{a}}$ \\
A. meleguetaEO $(5 \mu l)$ & $9.44 \pm 1.22^{\mathrm{a}}$ & $9.65 \pm 1.50^{\mathrm{a}}$ & $10.01 \pm 1.45^{\mathrm{a}}$ \\
A. meleguetaEO $(10 \mu l)$ & $10.46 \pm 1.20^{\mathrm{b}}$ & $11.84 \pm 1.42^{\mathrm{b}}$ & $12.32 \pm 1.26^{\mathrm{b}}$ \\
A. meleguetaEO $(15 \mu l)$ & $12.21 \pm 1.40^{\mathrm{ab}}$ & $13.60 \pm 1.25^{\mathrm{ab}}$ & $14.62 \pm 1.22^{\mathrm{ab}}$ \\
& & & \\
Control & $9.13 \pm 1.72^{\mathrm{a}}$ & $9.75 \pm 1.63^{\mathrm{a}}$ & $12.12 \pm 1.42^{\mathrm{a}}$ \\
D. tripetala EO $(5 \mu l)$ & $9.28 \pm 1.23^{\mathrm{a}}$ & $9.76 \pm 1.52^{\mathrm{a}}$ & $10.73 \pm 1.36^{\mathrm{a}}$ \\
D. tripetala EO $(10 \mu l)$ & $10.65 \pm 1.35^{\mathrm{b}}$ & $11.16 \pm 1.45^{\mathrm{b}}$ & $11.24 \pm 1.68^{\mathrm{b}}$ \\
D. tripetala EO $(15 \mu l)$ & $12.52 \pm 1.28^{\mathrm{ab}}$ & $14.22 \pm 1.36^{\mathrm{ab}}$ & $14.52 \pm 1.46^{\mathrm{ab}}$ \\
\hline
\end{tabular}

Means in the same column followed by the same letter(s) are not significantly different at 0.05 level of probability as determined by Tukey's test.

Effect of essential oil extracts from $A$. melegueta and $D$. tripetala on the reproductive potential and adult emergence of $R$. dominica

The result in Table 1 showed a significant $(\mathrm{P}<0.05)$ difference between the plant essential oils and the control in the mean number of $(\mathrm{F} 1)$ emergence. The $(\mathrm{F} 1)$ progeny emergence was significantly suppressed at

$15 \mu \mathrm{l}$ of the essential oils of the two spice plants with the highest suppression in the application of $15 \mu \mathrm{l}$ of $A$. melegueta essential oil (Table

2).

Table 2: Effect of essential oil extracts from $A$. melegueta and $D$. tripetala on the reproductive potential and adult emergence of $R$. dominica

\begin{tabular}{|c|c|c|c|}
\hline Treatments & $\begin{array}{l}\text { Mean adult } \\
\text { emergence }\end{array}$ & $\begin{array}{l}\text { Mean body weight } \\
\text { (mg) at } 5 \text { weeks }\end{array}$ & $\begin{array}{l}\text { Reproductive } \\
\text { potential determance } \\
(\%)\end{array}$ \\
\hline & \multicolumn{2}{|l|}{ A. melegueta } & A. \\
\hline Control & $3.255^{\mathrm{a}}$ & $5.22^{\mathrm{a}}$ & $0.00^{\mathrm{a}}$ \\
\hline Essentialoil $(5 \mu \mathrm{l})$ & $1.321^{\mathrm{b}}$ & $5.24^{\mathrm{a}}$ & $15.55^{\mathrm{b}}$ \\
\hline Essential Oil $(10 \mu \mathrm{l})$ & $1.122^{\mathrm{b}}$ & $5.21^{\mathrm{a}}$ & $16.58^{\mathrm{b}}$ \\
\hline \multirow[t]{2}{*}{ Essential oil $(15 \mu \mathrm{l})$} & $1.110^{\mathrm{c}}$ & $5.10^{\mathrm{a}}$ & $20.46^{c}$ \\
\hline & \multicolumn{3}{|l|}{ D. tripetala } \\
\hline Control & $2.254^{\mathrm{a}}$ & $5.36^{\mathrm{a}}$ & $0.00^{\mathrm{a}}$ \\
\hline Essential oil $(5 \mu \mathrm{l})$ & $1.722^{b}$ & $5.23^{\mathrm{a}}$ & $4.56^{\mathrm{b}}$ \\
\hline Essential oil $(10 \mu \mathrm{l})$ & $1.332^{\mathrm{b}}$ & $5.22^{\mathrm{a}}$ & $13.82^{\mathrm{a}}$ \\
\hline Essential oil $(15 \mu \mathrm{l})$ & $1.291^{\mathrm{c}}$ & $5.20^{\mathrm{a}}$ & $14.77^{\mathrm{c}}$ \\
\hline
\end{tabular}


Lawrence Ahmed Ugbe and Emmanuel B. Adie: Comparative analysis of the repellency activity of single compounds and the synthetic blends of semiochemicals from Aframomum melegueta (R.schum) and Dennittia tripetala (Bak.F) against Rhizopertha dominica in Calabar, Nigeria

Effect of diethyl ether fraction of $A$. melegueta, $D$. tripetala and their synthetic blend on the mortality count of $R$. dominica at 24,48 and 72 hours post treatment in the laboratory

The result showed a significant $(\mathrm{P}<0.05)$ difference between the treatments with the plants essential oils and control and also a significant $(\mathrm{P}<0.05)$ difference between the treatments with the single compounds and their synthetic blend, in terms of the mortality count of the insect pest at 24, 48, 72 hours post treatment.The mortality count of the insect in the treatment with diethyl ether from A. melegueta at 48 hours and 72 hours was higher than that of diethyl ether from $D$. tripetala. However, the synthetic blend of diethyl ether from the two spice plants recorded the highest mortality count of the insect pest at 48 hours and 72 hours than the single compounds (Table 3 ).

Table 3: Effect of diethyl ether fractions of $A$. melegueta, D. tripetala and their synthetic blend on the mortality count of $R$. dominica at 24,48 , and 72 hours post treatment in the laboratory

\begin{tabular}{|c|c|c|c|}
\hline & 24 hours & 48 hours & 72 hours \\
\hline Treatments & A. melegueta & & \\
\hline Control & $6.63 \pm 1.53^{\mathrm{a}}$ & $6.82 \pm 1.42^{\mathrm{a}}$ & $6.68 \pm 1.55^{\mathrm{a}}$ \\
\hline O $1 \mathrm{mg} / \mathrm{ml}(\mathrm{S})-2-$ Heptanol & $8.52 \pm 1.50^{b}$ & $8.65 \pm 1.08^{\mathrm{b}}$ & $9.55 \pm 1.83^{b}$ \\
\hline $0.6 \mathrm{mg} / \mathrm{ml}(\mathrm{S})-2-$ Heptyl acetate & $8.60 \pm 1.63^{b}$ & $10.62 \pm 1.21^{\mathrm{c}}$ & $12.68 \pm 1.82^{\mathrm{c}}$ \\
\hline $0.3 \mathrm{mg} / \mathrm{ml}(\mathrm{R})-$ linolool & $9.53 \pm 1.56^{\mathrm{b}}$ & $12.81 \pm 1.36 b^{c}$ & $15.65 \pm 1.84 b^{c}$ \\
\hline Synthetic blend $(10 \mu \mathrm{l})$ & $10.62 \pm 1.55^{\mathrm{c}}$ & $15.84 \pm 1.42^{\mathrm{d}}$ & $18.34 \pm 1.55^{\mathrm{d}}$ \\
\hline \multicolumn{4}{|l|}{ D. tripetala } \\
\hline Control & $7.73 \pm 1.52^{\mathrm{a}}$ & $6.65 \pm 1.56^{\mathrm{a}}$ & $6.45 \pm 1.54^{\mathrm{a}}$ \\
\hline $0.3 \mathrm{mg} / \mathrm{ml} \mathrm{1,} 3$ Cyclopentadien & $8.82 \pm 1.43^{\mathrm{b}}$ & $9.55 \pm 1.60^{\mathrm{b}}$ & $1063 \pm 1.56^{\mathrm{b}}$ \\
\hline $0.5 \mathrm{mg} / \mathrm{ml} \mathrm{1,6-Cyclodecadien}$ & $7.56 \pm 1.55^{\mathrm{c}}$ & $9.65 \pm 1.83^{\mathrm{b}}$ & $11.12 \pm 1.46^{\mathrm{b}}$ \\
\hline $0.2 \mathrm{mg} / \mathrm{ml}$ 2-Undecene & $7.66 \pm 1.54^{\mathrm{c}}$ & $10.24 \pm 1.67^{\mathrm{c}}$ & $15.63 \pm 1.45^{\mathrm{c}}$ \\
\hline Synthetic blend $(10 \mu \mathrm{l})$ & $10.64 \pm 1.83^{\mathrm{d}}$ & $12.46 \pm 1.52^{\mathrm{c}}$ & $16.42 \pm 1.50^{\mathrm{c}}$ \\
\hline
\end{tabular}

Effect of Diethyl ether fractions of A. melegueta, D. tripetala and their synthetic blend on the reproductive potential and adult emergence of $R$. dominica

There was a significant $(\mathrm{P}<0.05)$ difference between the control and the treatments of diethyl ether fraction from the two spice pants, and between the single compound of the diethyl ether fractions and their synthetic blend, in terms of the mean adult emergence and the percentage reproductive potential deterrence. In the control experiment involving the two spice plants, the mean adult emergence was higher than in the other treatments, since no plant extract was applied. The control in the two spice plants, also recorded zero percentage reproductive deterrence compared to the main adult emergence and the percentage reproductive potential deterrence for the other treatments with the plants extracts. The mean adult emergence in the treatment with synthetic blends of the two spice plants was zero recording between $30 \%$ reproductive potential deterrence for A. melegueta and $26 \%$ for $D$. tripetala. The suppression of the mean adult emergence by the synthetic blend of $A$. meleguetawas higher than that of D. tripetala. Also the percentage reproductive potential 
Lawrence Ahmed Ugbe and Emmanuel B. Adie: Comparative analysis of the repellency activity of single compounds and the synthetic blends of semiochemicals from Aframomum melegueta

(R.schum) and Dennittia tripetala (Bak.F) against Rhizopertha dominica in Calabar, Nigeria

deterrence of A. meleguetawas higher than that of D. tripetala (Table 4).

Table 4: Effect of Diethyl ether fractions of $A$. melegueta, D. tripetala and their synthetic blend on the reproduction potential and adult emergence of $R$. dominica in the laboratory

\begin{tabular}{|c|c|c|c|}
\hline & 24 hours & 48 hours & 72 hours \\
\hline Treatments & \multicolumn{3}{|c|}{ A. melegueta } \\
\hline Control & $3.831^{\mathrm{a}}$ & $3.62^{\mathrm{a}}$ & $0.00^{\mathrm{a}}$ \\
\hline $0.1 \mathrm{mg} / \mathrm{ml}(\mathrm{S})-2-H e p t a n o l$ & $1.422^{\mathrm{b}}$ & $3.51^{\mathrm{a}}$ & $16.82^{\mathrm{b}}$ \\
\hline $0.6 \mathrm{mg} / \mathrm{ml}(\mathrm{S})-2-\mathrm{Heptyl}$ acetate & $1.401^{\mathrm{b}}$ & $3.52^{\mathrm{a}}$ & $16.92^{\mathrm{b}}$ \\
\hline $0.3 \mathrm{mg} / \mathrm{ml}(\mathrm{R})-$ Linolool & $1.411^{\mathrm{b}}$ & $3.54^{\mathrm{a}}$ & $16.88^{\mathrm{c}}$ \\
\hline Synthetic blend $(10 \mu \mathrm{l})$ & $0.250^{\mathrm{c}}$ & $3.48^{\mathrm{a}}$ & $30.78^{\mathrm{d}}$ \\
\hline & & D. tripetala & \\
\hline Control & $2.981^{\mathrm{a}}$ & $3.64^{\mathrm{a}}$ & $0.00^{\mathrm{a}}$ \\
\hline $0.3 \mathrm{mg} / \mathrm{ml} 1,3-$ Cyclopentadien & $1.521^{\mathrm{b}}$ & $3.48^{\mathrm{a}}$ & $11.52^{\mathrm{b}}$ \\
\hline $0.5 \mathrm{mg} / \mathrm{ml} \mathrm{1,6-Cyclodecadien}$ & $1.482^{\mathrm{b}}$ & $3.38^{\mathrm{a}}$ & $11.48^{\mathrm{b}}$ \\
\hline $0.2 \mathrm{mg} / \mathrm{ml}$ 2-Undecene & $1.382^{\mathrm{b}}$ & $3.39^{\mathrm{a}}$ & $18.52^{\mathrm{c}}$ \\
\hline Synthetic blend $(10 \mu 1)$ & $1.441^{\mathrm{c}}$ & $3.55^{\mathrm{a}}$ & $28.24^{\mathrm{d}}$ \\
\hline
\end{tabular}

Means in the same column followed by the same letter(s) are not significantly different at 0.05 level of probality as determined by Tukey's test.

\section{Discussion}

There was no significant $(\mathrm{P}>0.05)$ difference in the mortality count of the adult $R$. dominica at 24,48 and 72 hours between $5 \mu 1$ and control. This is because the plants essential oils (EOs) concentration was too low at $5 \mu 1$ to cause any serious mortality of the adult $R$. dominica. However, at between $10 \mu \mathrm{l}$ and $15 \mu \mathrm{l}$, there was a significant $(\mathrm{P}<0.05)$ difference in the mortality count of $R$. dominica compared to the control. The significant $(\mathrm{P}<0.05)$ difference was attributed to the high concentrations, higher enough to cause the mortality of the insect pest. The cumulative mortality values at $10 \mu \mathrm{l}$ and $15 \mu \mathrm{l}$ at 72 hours post treatments, showed that essential oil (EO) from A. melegueta caused higher mortality of $R$. dominica compared to $10 \mu \mathrm{l}$ and $15 \mu \mathrm{l}$ of $D$. tripetala essential oil at 48 hours and 72 hours. The mortality of the insect however, appeared to increase as the concentration increases and as the number of days of exposure to all treatments except in the control. This result is in line with the report of Oparaeke and Kuhiep (2006) that the number of emerging S.zeamais in untreated (control) was significantly higher than those in the maize treated with $10 \mu \mathrm{l}$ and $15 \mu l$ concentration of powders of Aframomum melegueta and Zingiber officinale in an experiment.

On the reproductive potential and adult emergence, there was a significant $(\mathrm{P}<0.05)$ difference between the treatments and control, in terms of the number of new adult emergence. Essential oil (EO) from $A$. meleguata at $10 \mu \mathrm{l}$ and $15 \mu \mathrm{l}$ were significantly $(\mathrm{P}<0.05)$ toxic and repellant to $R$. dominica compared to control and at $5 \mu \mathrm{l}$ of the essential oil (EO). Essential oil of A. melegueta at $10 \mu 1$ and $15 \mu \mathrm{l}$ were more toxic to the insect than essential oil of $D$. tripetala at the same concentration of $10 \mu \mathrm{l}$ and $15 \mu 1$. However, the essential oils (EOs) were seen to suppressed oviposition to a certain level by the reproductive potential deterrence of the insect pest resulting in better protection of the stored cassava pellets from infestation and damage. 
Lawrence Ahmed Ugbe and Emmanuel B. Adie: Comparative analysis of the repellency activity of single compounds and the synthetic blends of semiochemicals from Aframomum melegueta (R.schum) and Dennittia tripetala (Bak.F) against Rhizopertha dominica in Calabar, Nigeria

The mean number of $\mathrm{F}_{1}$ progeny insects produced by $R$. dominica in the untreated (control) was significantly higher $(\mathrm{P}<0.05)$ than those treated with $10 \mu \mathrm{l}$ and $15 \mu \mathrm{l}$ doses of the essential oils (EOs) of the spice plants (Tables 2). This result is also in support of the report of Operaeke and kuhiep (2006) that the number of emerging $\mathrm{F}_{1} S$. zemais in untreated (control) was significantly higher than those emerging from the seeds treated with 10 and $10 \%$ (w/w) of powders of A. melegueta and $Z$. officinale, and that the efficacy of the powders depended on the dosage with higher doses providing greater protection and significantly fewer numbers of insect emerging. However, the treatments did not influence the weight of the emerged adults of the $R$. dominica which was determined by weighing with Sartorius weighing balance (Table 2). This finding is in agreement with Danho et al. (2001) who reported that emergent $S$. zeamais adult weight was not affected by competition on different quantities of host grains.

The result of the effect of diethyl ether fractions from A. melegueta, D. tripetala and their synthetic blends on the mortality of $R$. dominica showed a significant $(\mathrm{P}<0.05)$ difference between the treated and the untreated (control) and also a significant $(\mathrm{P}<0.05)$ difference between the other treatments and the synthetic blend. The application of $0.6 \mathrm{mg} / \mathrm{ml}(\mathrm{S})-2$ - heptyl acetate and $0.3 \mathrm{mg} / \mathrm{ml}(\mathrm{R})$ - linalool of $A$. melegueta for 72 hours was more toxic to the insect pest than $0.1 \mathrm{mg} / \mathrm{ml}(\mathrm{S})-2-$ heptanol of the same $A$. melegueta. It was also higher than the application of $0.3 \mathrm{mg} / \mathrm{ml} \quad 1, \quad 3-$ Cyclopentadiene, $0.2 \mathrm{mg} / \mathrm{ml}-2-$ Undecene and

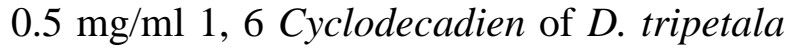
at 72 hours. However, application of synthetic blend of A. melegueta for 48 and 72 hours was highly significantly $(\mathrm{P}=0.01)$ different than all other treatments including the application of single compounds and synthelic blends of $D$. tripetala (Table 4).
The bioactivity of diethyl ether fractions of the two spice plants against the insect pest here in terms of mortality count showed that they were toxic to the insect. It is clear from this result that the bioactivity of the essential oils against the insect is attributed majorly to the diethyl ether fractions of the polar compound. The result is in agreement with the views of (Takabayashi and Dicke, 1996; Van Tolet al., 2007) who reported that the specific ratios of the behaviourally active compounds from florisil (R) diethyl ether fractions of A. melegueta and $Z$. officinale were responsible for the efficacy of their oils to repel maize weevil from stored maize.

On the effect of extracts from single compounds and their synthetic blend on the reproductive potential and adult emergence of $R$. dominica, the significant $\quad(\mathrm{P}<0.05)$ difference between the control and the treatment with the single compounds was as a result of the fact that extracts from the single compounds of $A$. melegueta and D. tripetala were toxic to the insect pest compared to the untreated (control). There was also a significant $(\mathrm{P}<0.05)$ difference between the treatments with single compounds and their synthetic blend. The sparate synthetic blend of the two spice plants were highly toxic to the insect pest than the single compounds. The synthetic blend of $A$. melegueta was more toxic to the insect than that of $D$. tripetala. However, the synthetic blend from each of the two spice plants, were able to suppress the adult emergence of the insect pest to zero thereby deterring the reproductive potential of the pest, compared to the single compounds (Table 5).

It was also observed in the treatments with the single compounds that the pungent adours from the essential oils could cause the insect to climb to the walls of the container soon after introduction thereby limiting adequate feeding and oviposition. This result is in agreement with the views of Adler, 
Lawrence Ahmed Ugbe and Emmanuel B. Adie: Comparative analysis of the repellency activity of single compounds and the synthetic blends of semiochemicals from Aframomum melegueta (R.schum) and Dennittia tripetala (Bak.F) against Rhizopertha dominica in Calabar, Nigeria

Ojimelukue, and Leon (2000) who observed that $S$. zeamais and $R$. dominica react to emissions from the non-host plants by making oriented movement away from the source of the emissions, and this could be deployed in stored products protection.

The toxicity of the essential oils (EOs) to the insect pest is as a result of the interaction with the insect nervous system, either by inhibiting the release of the enzyme acetylcholinesterase or by antagonizing the function of Octopamine receptors (Rosell, Quero, coll, and Guerrero, 2008). Octopamine is a biogenic amine that acts as neuro transmitter, neuro hormone and neuro modulator in invertebrates (Orchard, Ramirez and Lange, 1993). It is widely used in energy demanding behaviours such as flying, courting, egg-laying and jumping by all insects including crystaceans and spiders (Adanio, Linn and Hoy, 1995).

The single compounds individually could not have produce total protection of the stored cassava pellets, but the blend of each essential oil (EO) in their natural ratios gave significantly higher repellency and toxicity against $R$. dominica in the laboratory studies than the individual compounds. The blend produced percentage repellency (PR) equivalent to a class (iv) repellent with between 60-80 percent repellency (PR) classes of Juliana and SU (1983) from O to V, class $\mathrm{O}(\mathrm{PR}=0.15)$, class $1,(\mathrm{PR}=0.15-20 \%)$, class $11 \quad(\mathrm{PR}=20.1-40 \%)$, class III $(\mathrm{PR}=40.1-60 \%)$, class iv $(\mathrm{PR}=60.1-80 \%)$ and class v (PR-80.1-100\%).

The synthetic blend can be prepared and applied as protective bands around grain bulk or bags of cassava pellets or incorporated into packaging materials, such as sacking and paper to mask odours from stored cassava pellets or cereals or evoke non-host avoidance and repellent behaviours in the insects. The synthetic blends could also be used to treat the structure of an empty store to flush out hidden infestation before fresh cassava pellets or cereals are introduced (Emana, 1999). Also Bekeleand Hassanali (2001) observed that blend effects were responsible for the bioactivity of essential oil constituents of Ocimum kilimandscarius and $O$. Kenyense against stored products pests such as $S$. zeamais and $R$. dominica in Kenya.

\section{Conclusion}

To protect stored products especially cassava pellets, flour, seeds and grains from the destructive effects of insect pests is a common phenomenon in many countries of the world (Duke et al., 2003).However, there is great need to replace the inorganic pesticides with biopesticides such as extracts from plants' roots, seeds, fruit etc. the option of replacing the toxic synthetic inorganic pesticides, which are toxic to the user, consumers and the environment with plant base pesticides at a time when there are heightened public concerned over the hazardous effect of the synthetic pesticides is now receiving serious attention amongst scientists all over the globe. The result of the laboratory experiment conducted here, showed that the blends of the diethyl ether fractions of $A$. melegueta and $D$. tripetala have broad spectrum of bioactivity against $R$. dominica than the individual compounds. Identifying and testing the repellence and toxic effects of the chemical constituents of the essential oils (EOs) of the two spice plants and their blends in this study may provide further opportunities for their use in postharvest crop protection.

\section{References}

Adamo, S.A., Linn, C.E. and Hoy, R.R., 1995.The role to neurhomonal Octopamine during "fight or flight" behaviour in the field Cricket Gryllus bimaculatus. Journal of Experimental Biology, 198:1691-1700.

Adda, C., Borgemeister, C., Biliwa, A., Meikle, W.G., Markham, R.H and 
Lawrence Ahmed Ugbe and Emmanuel B. Adie: Comparative analysis of the repellency activity of single compounds and the synthetic blends of semiochemicals from Aframomum melegueta (R.schum) and Dennittia tripetala (Bak.F) against Rhizopertha dominica in Calabar, Nigeria

Peohling, H.M., 2002. Integrated Pest Management in post-harvest maize: a case study from the Republic of Togo (West Africa).Agriculture, Ecosystems and Environment, 93,:305-321.

Adler, C., Ojimelukwe, O. and Leon, T.A., 2000. Utilization of phytochemicals against stored product insects.Integrated Protection of Stored Products, 10BC Bulletin, 23:169-175.

Bekele, J., and Hassanali, A., 2001. Blend effects in the toxicity of the essential oil constituents of Ocimum kilimandscharius and $\mathrm{O}$. Kenyense (Labiateac) on two post-harvest insect pests. Phytochemistry, 57:385-391.

Bouda, H., Tapondjou, L.A., Fontam, D.A and Gumedzoe, M.Y.D., 2001. Effects of essential oils from leaves of Ageratum conyzoides, Lantana camara and Chromolaena odorata on the mortality of Sitophilus zeamais (Coleopteran: Curculionidae). Journal of Stored Products Research 37: 103109.

Danho, M., Gaspar, C. and Hanbruge, E., 2001. The impact of grain quantity on the biology of Sitophilus zeamais Motschulsky (Coleoptera: Curculionidae) Oviposition, distribution of eggs, adult emergence, body weight and sex ratio.Journal of Stored Products Research 38:259-266.

Duke, S.O. Baerson, S. R., Dayan, F.E., Rimando, A.M., Scheffler, B.E., Tellaz, M.R., Wedge, D.E., Schrader, K.K., Ahey, D.H., Arthur, F.H., De Lucca, A.J., Gibson, D.M., Harrison, H.F., Peterson, J.K., Gealy, D.R., Tworkoshi, T., Wilson, C.L. and Morris, J.B., 2003. United States Department of Agriculture, Agricultural Research Service, research on natural products for pest management. Pest Management Science, 59:708-717.
Emana, G., 1999. Use of botanical plants in the control of stored maize grain insect pests in Ethiopia: In CIMMYT and EARD (eds.) Maize Production Technology for the Future: challenges and opportunities. Proceedings of the $6^{\text {th }}$ Eastern and Southern Africa Regional Maize Conference, 21-25 September, 1998, Addis Ababa, Ethiopia, CIMMYT and EARD, pp. 105-108.

Holst, N., Meikle, W.G and Markham, R.H., 2002. Grain injury models for Prostephanus truncates (Coleopteran: Bostrichidea) and Sitophilus zeamais (Coleopteran: Curculionidea) in rural maize stores in West Africa. Journal of Economic Entomology, 93:1338-1346.

Hubert, J., Munzbergova, Z. and Santino, A., 2008. Plant volatile aldehydes as natural insecticides against stored product beetles.Pest Management Science, 64:57-64.

Isman, M.B., 2006. Botanical Insecticides, Deterrents, and Repellents in Modern Agriculture and an increasingly regulated World. Annual Review of Entomology, 51-45-66।

Juliana, G. and Su, H.C.F., 1983. Laboratory studies on several plant materials as insect repellents for protection of cereal grains. Journal of Economic Entomology, 76:154-157.

Meikle, W.G., Markham, R.H., Nansen, C., Hoist, N., Degbey, P., Azoma, K and Korie, S., 2002. Pest management in traditional maize stores in West Africa: a farmer's perspective. Journal of Economic Entomology, 95:1079-1088.

Ogendo, J.O. Kostyukovsky, M., Ravid, U., Mtasyoh, J.C., Deng, A.T., Omolo, E.O., Kariuki, S.T. and Shaaya, E., 2008. Bioactivity of Ocimum gratissinum, L. oil and two of its constituents against five insect pests attacking stored food products. Journal 
Lawrence Ahmed Ugbe and Emmanuel B. Adie: Comparative analysis of the repellency activity of single compounds and the synthetic blends of semiochemicals from Aframomum melegueta

(R.schum) and Dennittia tripetala (Bak.F) against Rhizopertha dominica in Calabar, Nigeria

of Stored Products Research, 44:328334.

Operaeke, A.M. and Kuhiep, G.C., 2006.Toxicity of powders from indigenous plants against Sitophilus zeamais Motsch. On Stored Grains. Nigeria Journal of Entomology, 3:216221.

Orchard, I., Ramirez, J.M. and Lange, A.B., 1993.A multi-functional role for Octapamine in locust flight.Annual Review of Entomology, 38: 227-249.

Rosell, G., Quero, C., Coll, J. and Guerreno, A., 2008. Biorational insecticides in pest management.Journal of Pesticide Science, 33:103-121.

Takabayashi, J. and Dicke, M., 1996. Plant carnivore mutualism through herbivore induced carnivore attractants. Trends in Plant Science, 1:109-113.

Ukeh, D.A., Birkett, M.A., Bruce, T.J.A., Allan, E.J., Pickett, J.A. and Mordue, (Luntz), A.J., 2010. Behavioural responses of the maize weevil, S.zeamais to host (maize grain) and non-host plant volatiles. Pest Management Science, 66:44-50.

Umoctok, S.B.A., Osuagwu, A.N., Udo, I.A., Idiongette, M.I, and Ukeh, D.A., 2009. Effects of Azadirachta indica products on the managements of Ootheca mutabilison Telfaira occidentalis in Calabar Southern Nigeria.Crop Production, 28:583-587.

Zar, J.H., 1999. Biostatistical analysis. $4^{\text {th }}$ edition.Prentice Hall, Upper Saddle River, New Jersey. 